\title{
Adolescent Coping Mechanisme At SMK Negeri 1 Medan On Sexual Harassment
}

\author{
Nurhannifah Rizky T \\ Sumatera Utara Faculty Of Nursing \\ E-mail: nurhannifahrizky@gmail.com
}

\begin{abstract}
Sexual harassment is all kinds of behavior that leads to sexual things that are carried out unilaterally and are not expected by the person who is the target, causing negative reactions such as shame, anger, hatred, offence, and so on in individuals who are victims of harassment. This study uses a descriptive design that aims to describe the coping mechanisms of adolescents at SMK Negeri 1 Medan against sexual harassment. The sample in this study were 94 teenagers at SMK Negeri 1 Medan. Sampling using the Stratified proportional random sampling method. The results showed that the adolescent's coping mechanism against sexual harassment was adaptive $(n=78 ; 83 \%)$. Adolescents used problem-focused coping mechanisms $(n=61 ; 65 \%)$ and using coping mechanisms that focus on emotions $(n=33 ; 35 \%)$. Adolescents at SMK Negeri 1 Medan use adaptive coping mechanisms to the problem of sexual harassment. Based on the results of the research, it is hoped that the education office and the school can work together with health workers to provide counseling regarding the problem of sexual harassment and efforts to deal with the problem of sexual harassment in adolescents. So that acts of sexual harassment can be faced by adolescents with adaptive coping and can reduce the incidence of sexual harassment in adolescents. Based on the results of the research, it is hoped that the education office and the school can work together with health workers to provide counseling regarding the problem of sexual harassment and efforts to deal with the problem of sexual harassment in adolescents. So that acts of sexual harassment can be faced by adolescents with adaptive coping and can reduce the incidence of sexual harassment in adolescents. Based on the results of the research, it is hoped that the education office and the school can work together with health workers to provide counseling regarding the problem of sexual harassment and efforts to deal with the problem of sexual harassment in adolescents. So that acts of sexual harassment can be faced by adolescents with adaptive coping and can reduce the incidence of sexual harassment in adolescents.
\end{abstract}

Keywords: Teenagers, Coping Mechanisme, Sexual Harassment

\section{Introduction}

Sexual harassment is an important issue because it emphasizes violence and gender inequality, is coercive and inhumane. Forcing women to be silent victims, and can encourage people to believe that sexual behavior deserves victimization. Sexual harassment occurs quite frequently in academia and in the workplace. (Matlin, 2004).

Basically any form of behavior that has a sexual content carried out by a person or a number of people but is not liked and is not expected by the person who is the target so that it causes negative consequences, such as shame, offence, humiliation, anger, loss of self-esteem, loss of chastity can be referred to as sexual harassment. Sexual harassment occurs when the perpetrator has more power than the victim. Power can be in the form of a higher job position, economic power, "power" of one gender over another, more personal numbers, and so on (Lestari and Wardhani, 2007).

Sexual harassment occurs repeatedly and continuously, but not many people understand and are sensitive about this issue. Sexual harassment is often considered a crime against morality alone. This kind of view is even supported by the state through the contents of the Criminal Code (KUHP). Sexual violence in the Criminal Code such as rape is considered a violation of decency. This categorization not only reduces the degree of rape, but also creates the view that sexual harassment is a matter of morality alone (Komnas Perempuan, 2010). 
Women who have been sexually harassed often quit their jobs or leave school; they may experience anxiety, fear, shame, depression, and reduced self-esteem. Men are generally more tolerant of sexual harassment than women. Victims of sexual harassment become less confident in their academic or work abilities. Common physical reactions to sexual harassment include headaches, eating disorders, and sleep disturbances. (Paludi \& Barickman, 1998 in Matlin, 2004).

Teenagers and their families as victims of criminal acts cannot allow sexual harassment to occur without any follow-up for perpetrators of sexual violence. Law Number 23 of 2003 concerning Child Protection also provides other forms of protection for victims, namely victims of sexual violence against children, contained in Article 18, Article 64 paragraphs (1) and (3), Article 69. Sanctions for perpetrators of crimes The crime of sexual violence against children is also regulated in Law Number 23 of 2003 concerning Child Protection which regulates it in articles 81 and 82.

\section{Method}

The research design used in this study is descriptive, which describes the coping mechanisms used by adolescents about sexual harassment.

The sampling technique used was random sampling method. Random sampling technique is given a serial number from number 1 to the last number on the Student Identification Number (NIS) in each stratum. Then a roll of paper with the numbers $1,2,3,4,5$. is made. One of the papers is taken and the number listed becomes the first serial number in sampling in each stratum. At the strata in class $X$, the sample required is 31 from a population of 433 , so the sample size is one-thirteenth of the population so that the jump number in the sample serial number is 13 . So if the number that comes out is number 2 then the sample number sequence is $2,15,28$, and so on, and if you have reached the last serial number but have not met the number of samples, then proceed back to the number above.

The research data was obtained by using a research instrument in the form of a questionnaire. This instrument consists of 2 parts, namely a demographic data questionnaire and a questionnaire regarding adolescent coping mechanisms regarding sexual harassment. The demographic data questionnaire includes age, gender, religion, ethnicity, pocket money/month, extracurricular activities, and parental education. Demographic data describe the frequency distribution and percentage of respondents' demographics.

The adolescent coping mechanism questionnaire on sexual harassment was prepared with a modified questionnaire from Tim Gelhaar et. al. (2007) on Adolescent Coping with Everyday Stressors on numbers 127 and modification of the questionnaire from Jan Sample (2012) on the Adolescent Coping Scale on numbers $1,2,7,12,16$, and 18 to add adolescent coping related to coping mechanisms focused on problems and coping mechanisms focus on emotions. The questionnaire used in the form of statements on coping mechanisms that focus on problems in statements 1-15 and statements 16-30 on coping mechanisms that focus on emotions. This instrument uses positive and negative statements. The scale used is the Guttman scale with Yes and No answer choices. The answer score is Yes $=1$ and the answer score is No $=0$. Statements number 1-15 are problem-focused coping mechanisms with answers $Y e s=1$, and no=0, while statements 16-30 are coping mechanisms that focus on emotions with answers $Y e s=0$, and No=1. The total coping score is 0-30 with an adaptive coping score of 16-30 and maladaptive with a score of 1-15.

\section{Analysis And Results}

\subsection{Characteristics of Respondents}

Based on data obtained from adolescents at SMK Negeri 1 Medan $(n=94)$ the majority of respondents were women $(n=86 ; 91.5 \%)$. Respondent age 17 years old $(n=47 ; 50 \%)$ and most of the respondents are Muslim $(\mathrm{n}=77 ; 81.9 \%)$ and $(\mathrm{n}=38 ; 40.4 \%)$ respondents are Bataknese with an average monthly allowance of < Rp.300,000 ( $\mathrm{n}=49 ; 52.1 \%$ ). On average, respondents did not participate in extracurricular activities $(n=49 ; 52.1 \%)$ while the most followed extracurricular activities by respondents was tutoring $(n=20 ; 21.3 \%)$. The education of the respondents' parents was mostly high school $(n=71 ; 75.5 \%)$. The data on the characteristics of the respondents are listed in table 1. 
Table 1. Frequency Distribution of Adolescent Coping Mechanisms Against Sexual Harassment at SMK N 1 Medan based on respondent characteristics $(\mathrm{n}=94)$

\begin{tabular}{|c|c|c|}
\hline Characteristics & Frequency (f) & Percentage (\%) \\
\hline \multicolumn{3}{|l|}{ Respondent's age } \\
\hline year & & \\
\hline \multirow[t]{2}{*}{ year } & 15 & 16 \\
\hline & 32 & 34 \\
\hline 17 years & 47 & 50 \\
\hline \multicolumn{3}{|l|}{ Gender Girls Boys } \\
\hline Religion & 86 & 91.5 \\
\hline Christian & 8 & 8.5 \\
\hline \multicolumn{3}{|l|}{ Islam } \\
\hline Ethnic group & 77 & 81.9 \\
\hline Batak Bugis & 17 & 18.1 \\
\hline \multicolumn{3}{|l|}{ Gayo } \\
\hline Javanese & 38 & 40.4 \\
\hline Karo Malay & 1 & 1.1 \\
\hline Minang & 2 & 2.1 \\
\hline Sundanese & 28 & 29.8 \\
\hline Pocket money & 1 & 1.1 \\
\hline$<$ IDR 300,000 & 8 & 8.5 \\
\hline IDR 300,000-600,000 & 15 & 16 \\
\hline ] IDR 600,000 & 1 & 1.1 \\
\hline \multicolumn{3}{|l|}{ Extracurricular activities } \\
\hline band & 49 & 52.1 \\
\hline Capoiera Tutoring & 36 & 38.3 \\
\hline Japan Club Pencak Silat & 9 & 9.6 \\
\hline \multicolumn{3}{|l|}{ PMR } \\
\hline No Theater & 2 & 2.1 \\
\hline Dance Scouts & 20 & 21.3 \\
\hline Parental Education & 3 & 3.2 \\
\hline Elementar & 1 & 1.1 \\
\hline y Middle & 3 & 3.2 \\
\hline \multirow[t]{7}{*}{ School } & 1 & 1.1 \\
\hline & 6 & 6.4 \\
\hline & 3 & 3.2 \\
\hline & 6 & 6.4 \\
\hline & 49 & 52.1 \\
\hline & 3 & 3.2 \\
\hline & 9 & 9.6 \\
\hline
\end{tabular}

\section{a. Adolescent coping mechanisms against sexual harassment}

The frequency distribution of respondents related to coping mechanisms is stated in table 2 . The results of the study stated that most of the respondents' coping mechanisms were adaptive (83\%).

Table 2 . Distribution of frequency and percentage of adolescent coping mechanisms against sexual harassment at SMK Negeri 1

\begin{tabular}{ccc} 
& Medan $(\mathrm{n}=94)$ & \\
\hline Coping Mechanism & Frequency $(\mathrm{f})$ & Percentage $(\%)$ \\
\hline Adaptive & 78 & 83 \\
Maladaptive & 16 & 17 \\
\hline
\end{tabular}

The frequency distribution of respondents related to the classification of coping mechanisms is stated in table 3. The results of the study stated that the majority of adolescents used problem-focused coping mechanisms (65\%).

Table 3. Distribution of frequency and percentage of adolescent coping with sexual harassment in SMK Negeri 1 Medan ( $n=94)$

\begin{tabular}{ccc} 
Coping Classification & Frequency $(f)$ & Percentage $(\%)$ \\
\hline Focus problem Focus & 61 & 65 \\
Emotion & 33 & 35 \\
\hline
\end{tabular}




\section{b. Coping Mechanisms}

The results showed that most of the adolescent coping mechanisms at SMK Negeri 1 Medan against sexual harassment were adaptive $(n=78 ; 83 \%)$. This is in line with research by Mulyana (2013) which states that the coping mechanism of adolescents at SMA Negeri 30 Jakarta is adaptive $(n=106 ; 55,2 \%)$ in dealing with a problem. These results indicate that the majority of adolescents can control their emotions and perceive a problem well. The coping mechanisms of adolescents at SMK Negeri 1 Medan against sexual harassment are adaptive $(n=78 ; 83 \%)$, this high percentage is because this study leads adolescents to threatening conditions from sexual harassment. This means that the incident of sexual harassment was not asked whether it had occurred or not.

Adaptive coping helps a person to deal with stress effectively and reduces the relationship with dangerous conditions around him. Maladaptive coping renders useless results under conditions that are harmful to a person and relates them to the stressful condition of the person (Kozier, 2004).

The results of the study related to the classification of adolescent coping mechanisms against sexual harassment showed that most of the adolescent coping mechanisms focused on problems $(n=61 ; 65 \%)$. This means that the cognitive development of adolescents is good so that adolescents quickly adapt to problems and prefer to face and resolve sexual harassment problems rather than choosing to deal with more emotional problems when facing problems.

\section{Conclusion}

The study was conducted on 94 adolescents at SMK Negeri 1 Medan. The results showed that the coping mechanism of youth in SMK Negeri 1 Medan was adaptive. Teenagers use more problem-focused coping mechanisms. Thus, the researchers concluded that adolescents at SMK Negeri 1 Medan use adaptive coping mechanisms to the problem of sexual harassment because they are able to control coping mechanisms that focus on emotions so that adolescents face problems by using problem-focused coping mechanisms.

\section{References}

Arikunto, S. (2010). Research Procedure: A Practical Approach. (revised edition). Jakarta: Rineka Cipta

Dario, Agoes. (2004). Adolescent Developmental Psychology. Bogor: Ghalia Indonesia

Desmond, Deirdre M., Shevlin, Mark., MacLachlan, Malcolm. (2005). Dimensional analysis of the coping strategy indicator in a sample of elderly veterans with acquired limb amputations. Journal of Personality and Individual Differences, 40, 249-259.

International Labor Organization (2013). Sexual harassment. Asian Decent Work

Kozier, B., Erb, G., Berman, A., Snyder, SJ (2004). Fundamentals of Nursing, Concepts, Process, and Practice (7th ed). New Jersey: Pearson Education, Inc

National Commission for Women (2010). http://www.komnasperempuan.or.id accessed on September 25, 2013 at 20:47

National Commission for Women (2013). http://www.komnasperempuan.or.id accessed on 26 September 2013 at 22:41

Matlin, M.W. (2004). The Psychology of Women (5th ed). California: Wadsworth Mulyana. (2013). Overview of Adolescent Coping Mechanisms at SMA N 30 Jakarta.

Undergraduate Theses. Depok: Program Bachelor Faculty KnowledgeNursing University of Indonesia

Notoatmodjo, Soekodjo (2010). Behavioral Health Sciences. Jakarta: Rineka Cipta Nursalam (2003). Draft \& Application Methodology Study Knowledge Nursing: Guidelines for Thesis, Thesis, and Research Instruments. Jakarta: Salemba Medika.

Papalia, Diane E., Sally W. Old, \& Ruth D. Feldman. (2008). Human Development (9th ed). New Jersey America: Pearson Education, Inc. 
Potter, PA \& Perry, AG (2005). Nursing Fundamental Textbook: Concepts, Processes \& Practices Volume 1 (4th ed). Jakarta: EGC.

Ridwan. (2004). Methods and Techniques for Compiling Thesis. Bandung: Alphabeta.

Rimawati, Nanda. (2013). Factors Associated with Risky Sexual Behavior of Adolescents in Three State Senior High Schools Class X and XI in Bengkulu City. Theses. Depok: Public Health Study Program, Specializing in Reproductive Health, Faculty of Public Health, University of Indonesia.

Samples, Jan. (2012). Adolescent Coping Scale (2nd ed). Published by The Australian Council for Educational Research.

Santrock, John W. (2007). Child Development, 11th edition vol 1.Jakarta: Erlangga.

Simanjuntak, Risma Hotmaida. (2013). Organizational Structure of SMK N 1 Sindoro Medan. smknegeri1sindoromedan.blogspot.com accessed on June 29, 2014 at 21:42

Stuart, GW \& Laraia, MT (2005). Principles and Practice of Psychiatric Nursing (8th ed).St.Louis: Mosby

Stuart, GW \& Sudden, JS (2005). Principles and Practice of Psychiatric Nursing (4th ed). St. Louis: Mosby year book

Team Gelhaar et.al. (2007). Adolescent Coping with Everyday Stressors: A seven-nation Study of Youth from Central, Eastern, Southern, and Northern Europe. European Journal of Developmental Psychology, 4(2),129-156

Wardani, Yurika Fauzia., Lestari, Weny. (2007). Post Traumatic Stress Disorder in Victims of Sexual Harassment and Rape. Journal. Surabaya: Center for Health System and Policy Research and Development

Wuryani, SE (2008). Sex Education for Families. Jakarta: Index 